\title{
The Judicial Politics of Burqa Bans in Belgium and Spain-Socio-Legal Field Dynamics and the Standardization of Justificatory Repertoires
}

\author{
Marian Burchardt, Zeynep Yanasmayan, and Matthias Koenig
}

\begin{abstract}
Over the past decade, controversies over Muslim women's face veiling have become increasingly widespread in societies across Europe. This article comparatively explores the socio-legal dynamics of claims making by proponents and opponents of prohibiting full-face coverings in Belgium and Spain. In Belgium, a federal ban of full-face coverings was adopted in July 2011 and, after intensive judicial struggles, received judicial validation by the Constitutional Court in 2012. In Spain, local burqa controversies led to municipal bans in the region of Catalonia in 2010, which were annulled by the Supreme Court in 2013 after effective legal counter-mobilizations. In spite of the diverging legal outcomes, we argue that justificatory repertoires have become increasingly standardized as burqa controversies are transposed from locally embedded political fields to transnationally structured judicial fields. We suggest that this standardization of justificatory repertoires in the long run facilitates the rapid spread of burqa bans across Europe.
\end{abstract}

\section{INTRODUCTION}

Over the past decade, national governments and subnational administrations have become embroiled in heated debates about face coverings (niqabs and burqas) ${ }^{1}$ throughout Europe. It is striking how rapidly legal restrictions on their use in public spaces have spread across the continent (see Grillo and Shah 2012; Ferrari and Pastorelli 2013). France was the first country to adopt a nationwide restriction of face

Marian Burchardt is a professor of sociology and area studies at the University of Leipzig, and may be contacted at marian.burchardt@uni-leipzig.de.

Zeynep Yanasmayan is a senior research fellow and coordinator of the program "The Challenges of Migration, Integration and Exclusion" at the Max Planck Institute for Social Anthropology in Halle/ Saale.

Matthias Koenig is a professor of sociology at the University of Göttingen and Max Planck Fellow at the Max Planck Institute for the Study of Religious and Ethnic Diversity.

Research for this article has been generously funded by the Max Planck Fellow Group "Governance of Cultural Diversity" based at the Max Planck Institute for the Study of Religious and Ethnic Diversity. The authors are grateful for critical comments and helpful suggestions provided by the external reviewers of LSI.

1. We are fully aware of the differences between the meaning of the different forms of face covering used by Muslim women. In this article, we employ the vernacular term "burqa" as used, or rather misused, in political and legal discourses because it encapsulates important political dimensions of the debate. As Moors (2009) suggests, the preference in much political discourse for burqa, as opposed to niqab, has to do with the intention to conjure up images of the Taliban regime and its barbarism as the real opponent in the controversy. 
coverings in a widely publicized law in 2010, and Belgium followed suit in 2011. In its famous decision S.A.S. v. France (2014), as well as in the most recent Dakir v. Belgium (2017) and Belcacemi and Oussar v. Belgium (2017) decisions, the European Court of Human Rights (ECtHR) in Strasbourg upheld such burqa bans. While potentially limiting the individual's freedom of religion, the court deemed banning full-face coverings compatible with human rights requirements as long as it was based in law and served a legitimate aim, such as the maintenance of public order and its underlying value of "living together." Today, local bans exist in Italy (since 2016), Switzerland (since 2013), and Russia (since 2013). Bulgaria prohibited Muslim women's face coverings on public transport in 2016, while the Netherlands approved plans to ban face coverings in government buildings, schools, hospitals, and on public transport. In Austria, a ban on full-face veils in public spaces came into force in the wake of national elections in October 2017. ${ }^{2}$

While burqa bans have given rise to intense normative controversies among political and legal theorists (Laborde 2012; Nussbaum 2012; Ouald Chaib and Brems 2013), social scientists have only recently started to describe and explain their rapid spread across Europe. In exploring the socio-legal dynamics underlying the spread of burqa bans, they have mainly pursued three different agendas. First, many scholars have focused on the specter of Islamophobia and populism, which undeniably haunts the politics of burqa bans. All across Europe, so the argument goes, changing macro-discursive contexts have allowed face veiling bans to be portrayed as promoting "Western values" such as gender equality, individual freedom, and reciprocity in communication, as erecting barriers against Islamic radicalism, as promulgating a progressive Islam that is compatible with modernity, and as freeing Muslim women from patriarchal pressure and safeguarding human dignity (Moors 2009). Such arguments need to be placed in wider debates on the relationships between multiculturalism, feminism, and cultural relativism (Volpp 2001). They are also reminiscent of Abu-Lughod's (2013) observations about the imperial and neocolonial gesture manifest in the notion of Muslim women in need of "being saved." Second, macro-institutional approaches as advanced by comparative political scientists and sociologists have attempted to explain country-specific variations in the timing and content of restrictive regulations as resulting from historically pathdependent state policies toward religion, citizenship regimes, idioms of nationhood, or political party politics. For instance, the restriction of full-face coverings in France has been regarded as reflecting its particular political culture of militant or assertive secularism (Fournier and See 2012). ${ }^{3}$ Not unlike macro-discursive approaches, some authors have regarded these restrictions as characteristic of a general secularist onslaught on publicly visible religion (Amiraux 2013), or have drawn attention to the fact that burqa bans serve to distinguish desirable from undesirable religions (Mahmood 2006) and to target versions of Islam deemed incompatible

2. Significantly, there are also bans outside Europe. In Chad, as well as in parts of Niger, Cameroon, Gabon, and Congo-Brazzaville, face veil bans were passed in response to Islamist suicide attacks. See http:// www.telegraph.co.uk/news/2016/05/02/west-african-states-with-181-million-muslims-support-banningthe/.

3. On France, see also Joppke and Torpey (2013) and de Galembert (2014); on Belgium, see Brems, Vrielink, and Ouald Chaib (2013) and Delgrange (2014); on Canada, see Beaman (2013). 
with Western liberal democracy (Joppke 2013; Burchardt, Griera, and GarcíaRomeral 2015).

A third line of study, based on thick ethnographic descriptions and in-depth interviews with face-veiling women, has by contrast explored the variable subjective meaning of face coverings as religious symbols, expressions of piety, or forms of spirituality in everyday life (Parvez 2011; Brems 2014; Selby 2014). This micro-level research has largely found that - contrary to public stereotypes - the use of the niqab was often self-chosen, an outcome of spiritual journeys tellingly pursued not only by Muslims with migration backgrounds, but also by native converts.

Neither macro- nor micro-level approaches, however, have fully captured the precise socio-legal dynamics that undergird the phenomenal spread of burqa bans across rather different political settings in Europe. In this article, we therefore advance a meso-level analysis of contestations over full-face coverings that sheds light on the role of judicial fields in transforming justificatory repertoires as employed in public or political discourse. Our analytical focus is hence on judicial battles over burqa bans. Although often approved by public opinion, political banning initiatives have in fact faced considerable resistance-from Muslims, human rights associations, and activist lawyers-who have all judicially challenged what they perceived as infringement of constitutional and human rights. As a consequence, constitutional and international courts have become key arbiters over the legitimacy of burqa bans. Controversies over full-face coverings thus attest to what an emerging literature has called the "judicialization" of politics, which has affected the politics of religious difference more broadly (Hirschl 2008; de Galembert and Koenig 2014). In that literature, the term "judicialization" refers not only to the long-term rise to power of constitutional and international courts, but also to the socio-legal dynamics accompanying the transfer of concrete disputes from political into judicial fields. We draw on, and further elaborate, major analytical insights of that literature by tracing the socio-legal dynamics of judicialization through which local burqa disputes become disembedded in a two-fold sense: first, by being transferred from political into the judicial fields and, second, by moving from local to national and to transnationally structured fields. Our key argument is that as burqa disputes are transposed from locally embedded political fields to transnationally situated judicial fields, the justificatory repertoires employed by disputing actors are increasingly standardized. More specifically, judicialization narrows the range of legitimate arguments made for and against burqa bans, thus contributing to the production of legal templates routinely employed in subsequent disputes. Close attention to these meso-level socio-legal dynamics is crucial, in our view, to capture the rapid spread of burqa bans fully.

We develop our argument by comparing socio-legal dispute dynamics concerning prohibitions of full-face coverings in Belgium and Spain. Previous socio-legal studies have mostly focused on France as an early adopter of such prohibitions. The French law against full-face coverings (2010) is indeed a textbook example of judicial politics in which government and parliament entered into sustained dialogue with the Court Constitutionnel to design a legally defensible prohibition (de Galembert 2014), which even passed muster by the ECtHR in the S.A.S. case. Compared to the often-told French burqa saga (see also Hunter-Henin 2012; Baehr and 
Gordon 2013), the cases of Belgium and Spain have received less attention in the literature. In Belgium, where local initiatives date back as early as 2002, a federal ban of full-face coverings was adopted in June 2011 and, after intensive judicial struggles, received judicial validation by the Constitutional Court in 2012. In Spain, local burqa controversies led to municipal bans in the region of Catalonia in 2010, which, however, were annulled by the Supreme Court in 2013 after effective legal counter-mobilizations.

Our selection of these two cases of burqa controversies is motivated by two analytical considerations. First, both cases differ starkly in terms of their macrodiscursive and macro-institutional configurations and with respect to the specific outcomes of apex court rulings concerning full-face coverings. Thus, they provide fertile ground to explore our argument that the judicialization of disputes tends to standardize justificatory repertoires. Second, both burqa controversies occurred prior to S.A.S. Hence, they shed light on socio-legal dynamics occurring in a situation of uncertainty concerning transnational institutional frameworks. In short, a comparative analysis of Belgium and Spain promises strong analytical leverage in assessing how the judicialization of burqa bans has intervened in the meso-level dynamics. Our comparative analysis of Belgian and Spanish burqa controversies is based on archival material, including complaints, decisions, and third-party interventions in courts, as well as on twenty semi-structured expert interviews conducted with judges, lawyers, politicians, and human rights activists between 2014 and 2015. All interviews were fully transcribed and coded with a focus on conflict evolution, types of arguments, and conflict outcomes. ${ }^{4}$

We start by situating our approach in the wider law and society literature, highlighting the need for a more rigorous analysis of socio-legal field dynamics that account for shifting justificatory repertoires in the course of judicialization. We then present the findings of our two case studies, starting with Belgium and then turning to Spain. In both cases, we follow burqa controversies as they are disembedded from local to national arenas, from political to judicial fields, and we identify the distinctive actor constellations and justificatory repertoires that characterize each stage of these controversies. We conclude by highlighting the standardizing effects of judicial fields and by spelling out some implication for future research.

\section{THEORIZING JUDICIAL POLITICS OF RELIGIOUS DIFFERENCE}

Our analysis of burqa controversies in Belgium and Spain draws on broader debates over the judicialization of politics. Accompanying the worldwide proliferation of constitutional and international bills of rights, judicialization is typically conceived as a large-scale transformation in which supreme courts are invested with increased authority over crucial political questions (Ferejohn 2002; Hirschl 2008). A sophisticated literature in law and society research, comparative politics, and sociology has offered explanations of the causes and consequences of judicialization. Focusing on causes, scholars have asked why courts have become empowered in the

4. All quotes from interviews are our own translations from French, Spanish, or Catalan. 
first place and why politicians delegate certain issues to the judiciary (Ginsburg 2003). In terms of consequences, scholars have identified various ways in which judicialization affects political action. These include direct effects where empowered supreme courts, through judicial review or case law, can require laws to be amended or annulled. They also include indirect effects, notably what Stone Sweet $(2010,74)$ has called the "pedagogical authority" of constitutional courts; their existing and anticipated jurisprudence sets the framework within which bills are discussed, at times leading to autolimitation on the part of lawmakers to avoid rebuttal in court. Finally, judicialization affects political action by means of shaping rights consciousness and creating legal opportunity structures for citizens' participation and social movement mobilization. As a consequence, citizens, interest groups, and movement activists routinely use strategic litigation to contest public policies they oppose (McCann 1994). A key concern underlying the entire literature is, of course, to assess whether and how the judicialization of politics advances or undermines the claims making of politically subordinate minority groups (see notably Rosenberg 1991; Epp 1998; for a review, see Roesler 2007). It is this normative concern that also undergirds recent attempts to explore the judicial politics of religious difference (for a review, see de Galembert and Koenig 2014).

But despite recent advances in exploring the judicial politics of religious difference, the literature has paid less attention to the meso-level dynamics through which political claims and their justifications are fundamentally altered in the course of judicialization. Although it is often assumed that judicialization has broadly affected the very terms of political discourse, only few studies have scrutinized how exactly claims, frames, and arguments are modified, expanded, or reduced as political conflicts are transferred into the judicial arena (on this point, see Pedriana 2006; Roesler 2007, 575). In what follows, we propose that such meso-level dynamics are best captured by analytical tools developed in sociological neoinstitutionalism and field theory.

Sociological neo-institutionalism regards social action as embedded in broader institutional environments that contain cognitive and normative templates, which actors typically employ in situations of uncertainty (see notably DiMaggio and Powell 1983). As neo-institutionalists emphasize, the availability of legitimate templates, scripts, or models promoted by international organizations, transnational epistemic communities, and professionals who are disembedded from local contexts, generates a strong institutional drift toward convergence or "isomorphism" across otherwise different contexts of action. Transnational law is a case in point, as it shapes collective identities as well as mobilization strategies of social activists (Kay 2011). Neo-institutional insights have been fruitfully employed to account for converging trends in the politics of religious difference in Europe in light of an expansive jurisprudence of the ECtHR (Koenig 2015). In our two case studies on Belgium and Spain, we add further nuance to these insights by exploring how burqa controversies that originate in distinctive local and national settings become successively embedded in broader transnational processes. To understand when and how actors draw on and, indeed, shape transnationally circulating templates, however, requires greater attention to the socio-legal field dynamics. 
Field theory regards the social world as composed of multiple sites, arenas, or fields characterized by distinctive power relations and symbolic logics, which enable and constrain the strategies of actors, including both incumbents and challengers (see Fligstein and McAdam 2012). The legal field can thus be conceptualized, drawing on Bourdieu (1987), as a "symbolic terrain with its own networks, hierarchical relationships, and expertise, and more generally its own rules of the game" (Dezalay and Garth 1996, 16-17). Crucially, power relations and symbolic logics characteristic for legal and, more specifically, judicial fields differ from those that characterize the political field; this is precisely the reason why courts can potentially bolster the claims of minorities who challenge political power relations. Understanding the meso-level dynamics that undergird judicial battles over religious difference therefore requires exploring how claims making by both challengers and incumbents is transformed when being transposed from political to judicial fields. Such transposition requires both types of actors, or so we argue, to engage in practices of translation that align their claims (or claims of others) with field-specific symbolic logics or rationalities. Ultimately, these practices contribute to the standardization of what we call justificatory repertoires, by which we mean the range of legitimate arguments actors marshal to generate public support for their claims and to immunize them against critique. Once disputes enter judicial fields, they narrow the range of legitimate arguments that actors can publicly advance in subsequent disputes, thus having standardizing effects even in the absence of converging judicial decisions.

That entry into the judicial field alters the range of legitimate arguments available to actors is, in fact, suggested by previous research on judicial politics of religious difference. In France, for instance, the extension of headscarf prohibition from the public to the private domain, and the ultimate judicial sanction in what is known as the "Baby Loup affair," has required actors constantly to refashion their interpretations of legal concepts such as laïcité, neutrality or public order (Hennette-Vauchez and Valentin 2014). Likewise, contestations over the French burqa ban have been accompanied by complex negotiations between activists, legal experts, politicians, and high court judges, which ultimately resulted in judicial justification of the ban (Fredette 2015). In our two cases studies on burqa controversies in Belgium and Spain, we show that the transfer of disputes into judicial fields generally standardizes the justificatory repertoires available to both proponents and opponents of burqa bans, requiring them to frame their claims in terms of individual rights or public order considerations. This way judicial field dynamics produce a standardization of normative arguments that is, in the long run, more consequential for public discourse over religious difference than the outcome of a given court ruling in a given particular case; it is this production of standardized legal templates that prepares the ground for the rapid spread of burqa bans.

\section{CONTESTING THE BURQA BAN IN BELGIUM}

Belgium is one of the few countries in Europe where a nationwide ban on face veiling is currently in force. Unlike in France, however, this ban does not form part

5. The "Baby Loup" affair (2008-2014) originated in a Muslim employee's claim against the prohibition of the foulard in a private daycare center and gave rise to multilayered and multistakeholder judicial battles. 
of a general public policy of assertive secularism (Kuru 2009). In fact, as the historical battle between state and church occurred under conditions of deep denominational cleavage, the secular settlement in Belgium consisted of "consociational" agreements that successively granted public recognition to Catholicism, Protestantism, Judaism, Anglicanism, Orthodoxy, and secular humanism. A core element of the Belgian consociational pacts for the recognition of religious or philosophical communities is the imperative condition that they be represented through a stable organization (Laurence 2012, 182). Even though Islam relatively quickly benefited from this conditional pluralism, receiving official recognition as early as 1974, problems of establishing a representative body have hindered full-fledged institutionalization of Islam to date (see Kanmaz 2002; Yanasmayan 2010). As we shall see, this context has left an impact on judicial controversies over full-face veiling, notably on the reluctance of the Islamic representative body, the so-called Muslim Executive in Belgium, to engage in advocacy against the ban.

Tracing the genealogy of the Belgian ban on the face veil shows how a wide array of arguments entwining local security practices with national identity discourses was effectively reduced to legal templates, more specifically focusing on the balance between respect for religious freedom and concerns of public safety and viure ensemble through the transfer from the political to the judicial field. The initial repertoire of arguments deployed in favor of a ban in the parliamentary debates encompassed (1) the fight against the perceived growth of Islamism, (2) the promotion of Western values such as gender equality, (3) support for the emancipation of Muslim communities to foster a harmonious viure ensemble, (4) safety concerns, and (5) the legal unity of the kingdom that was putatively undermined by existing local bans. In parliament, the ban was little contested, the only worry being the potential clash of a blanket ban with fundamental freedoms. ${ }^{6}$

The activists and NGOs that appealed to the Constitutional Court to challenge these political initiatives have also used a variety of justificatory repertoires for their claims, even if their arguments were from the very beginning framed in the legalistic language of fundamental freedoms. Apart from pointing out (1) the interference of the ban with the religious practices of a specific group of Muslims, they criticized (2) the principle of the permanent identifiability required from everyone in the public space. Moreover, while some opponents maintained that (3) the law discriminated against and stigmatized Muslim communities, others had a more modest attitude, objecting to (4) the criminalization, but not to the restriction on burqa wearing as a practice. The court mainly picked up on the arguments relating to the violation of religious freedom, thus focusing the debate strictly on the appropriate reasons for limiting this freedom, which granted priority to concerns of public safety and vivre ensemble. As the following analysis demonstrates, the justificatory repertoires employed by the proponents of the ban have thus become highly standardized in the course of judicialization. Arguments focusing on threats of radicalism almost entirely disappeared from public discourse, while issues of public

6. This is perhaps not surprising in light of the fact that the member of parliament who openly opposed the ban has a legal background herself. 
security and viure ensemble, which had greater chances of surviving constitutional scrutiny, gained considerable prominence.

\section{A. Local Actor Constellations and the Early Judicialization of Burqa Bans}

Several Belgian municipalities have long had provisions prohibiting the wearing of masks or other forms of disguise in the public space, except for specific festivities such as the period of Carnival. From 2004 onward, not only were these provisions reinterpreted to include Muslim women's face veils, but also a new set of regulations prohibiting appearing in public in an unidentifiable manner or with a covered face were promulgated (Vrielink, Ouald Chaib, and Brems 2013). These latter regulations, as opposed to the historical ones, were specifically geared to addressing issues with women wearing face veils. To facilitate the task of the municipalities, the governments of the Flemish and Brussels-Capital regions have provided them with sample regulations that could serve as a model. Before the federal ban was enacted, several municipalities, including major cities such as Antwerp, Brussels, and Ghent, had instituted such a ban. However, these regulations did not go uncontested at the local level. Two contradictory court decisions, which were later used by the federal legislators as evidence of legal uncertainty in the territories of the kingdom, are worth mentioning.

The first decision came in June 2006, when the Police Court of Maaseik, a small town in the Flemish region, became one of the first municipalities to inquire about and apply the standard regulation model provided by the Flemish government. The case involved a face-veil-wearing woman who objected to being fined and whose appeal was rejected by the Police Court, which did not find violations of the freedom of religion, or of the principle of equality (Vrielink, Ouald Chaib, and Brems 2013). Almost five years later, another local court decision rejected the judgment of the Maaseik Police Court. The Police Court of Brussels ruled in January 2011 in favor of a woman who had been fined twice with an interval of two months in 2009 for wearing a face veil. It is important to note here that this is the very same woman who brought the case first to the Belgian constitutional court and then to the ECtHR, Belcacemi and Oussar v Belgium (2017). This early judicialization of the dispute therefore had an impact on the unfolding of later episodes, as well as on the repertoires of argumentation, which prioritized the symbolic logic of the judicial field. The judgment makes extensive reference to Article 9 of the European Convention of Human Rights and to the pre-S.A.S. case law of the ECtHR, and it concludes that the municipal regulation is incompatible with religious freedom, since, despite serving a legitimate aim, which in this case is public security, it offers a disproportionate response.

\section{B. Political Actor Constellations and Parliamentary Burqa Controversies}

A variety of arguments was mobilized in the political field, ranging from legal unity across the kingdom to gender equality, from public safety to the integration of 
Muslim communities. Despite the neutral language of the law, the political debate prior to its adoption almost exclusively focused on the Islamic face veil, and strong emphasis was put on the protection of "Western values" as a justificatory argument. Moreover, while there was no concrete case of radicalization that stimulated the ban, a diffuse fear of fundamentalism was evident in parliamentary debates.

Even though the genesis of burqa contestations can be traced back to the local arena, the federal parliament did not lag behind. Legislative attempts were initiated by the extreme right-wing party Vlaams Blok as early as 2004. Even though this initiative did not find much support in either chamber of parliament at the time, in the long term, the legislative desire to ban the Islamic face veil has been extended to the center of the political spectrum. Different political parties, such as the Christian Democrats, Liberals, and Vlaams Belang, a reincarnation of Vlaams Blok following the latter's conviction for using racist language, submitted proposals during the 2007-2010 legislative term, which led to the eventual adoption of the April 29, 2010 law by the House of Parliamentarians, the lower house of the bicameral Belgian system. Before the Senate had a chance to review the bill, the government fell, and both houses were dissolved. Nearly one year after the subsequent elections in 2010, the Belgian parliament revisited the earlier proposals and adopted the law criminalizing the face veil and all other garments that cover the face fully or partially. The "Act of 1 June 2011 instituting a prohibition on wearing clothing that covers the face in whole or in part," which adds an Article 563bis to the Belgian Criminal Code, received near-unanimous approval (one nay, two abstentions) from members of parliament. With the Senate opting out of a review this time round, the federal ban on the face veil saw the light of day amid the most serious political deadlock in the kingdom, with 445 days without a government. ${ }^{7}$

Despite being passed twice, a sense of urgency dominated the parliamentary debates, leading to the omission of a few stages of the sort taken in France prior to the adoption of the law, such as holding hearings with civil society representatives and requesting the Council of State for an opinion. As our interviewee at the Centre for Equal Opportunities and Opposition to Racism, a Belgian government agency that predominantly deals with discrimination cases, put it: "There was a kind of competition to be the first state to ban the face veil in Europe." Even though that race was lost due to the unexpected fall of the government, which put Belgium behind France in this respect, the interest in legislating did not fade away. On the contrary, the April 2010 attempt had shown the uncontested nature of this law and gave the politicians a golden opportunity to reaffirm national unity at a time when it was to be found nowhere else. Therefore, Fadil (2014) is right in suggesting that the Belgian ban was in the first place an expression of sovereign state power at a moment of deep institutional crisis.

Like the Lleida city government in Spain, which sought to promote a political agenda regardless of the legal outcome (see below), Belgian parliamentarians were

7. The majority of other legislation adopted in this limbo period, already considerably reduced in amount, was geared to fulfilling Belgium's international obligations or to managing the economic situation (Delgrange 2014). The law on banning of face veils, a significant exception, makes one wonder as to the reasons for the rush to legislate. 
more interested in "sending a message," and they did not want to take the risk of it being undermined through its possible rejection by the Council of State, as was the case in France. In the words of one deputy from the Francophone liberal party (Mouvement Réformateur), as reported in the Parliamentary Document (DOC 53 0219/004, 11, April 18, 2011):

A clear message should be conveyed to some representatives of the judiciary on our values and public safety: the political world will maintain its position. Aside from public safety, our core values are at stake here. These are also shared by a number of Muslims, but this is a first step against Islamism, which is currently growing in our country. Just like France, which has taken steps in the matter, the adoption of this bill is an outstanding message to the world about owning up to our values of women's dignity and liberty and Enlightenment.

As these words show, central to this initiative was the desire to disseminate an image of a cohesive society to which certain values such as gender equality are a sine qua non of membership. The interventions in parliament were different shades of the same color, with strong agreement on how burqas allegedly dehumanized women. For an overwhelming majority, the oppression of women that is incarnated in the burqa touches the very heart of the principle of viure ensemble. While some political actors perceive wearing a face veil as an act of rejection of "Western and Enlightenment values," others see it at best as a huge impediment to further integration and emancipation. Therefore, the ban is conceived as a first step in an "emancipatory mission" that needs to be continued through other measures at the community level.

Yet, for a minority of deputies, it is not so much what the burqa symbolizes for gender equality that damages viure ensemble, but the very act of hiding one's face. The lack of identifiability that comes with it is thought to hinder dialogue, sociability, and civility, which are essential values of an open society. It will be seen later that it is in fact this particular conceptualization of vivre ensemble that has gained ground in the judicial debate in both Belgium and Spain, as well as in the ECtHR.

Public security was also one of the main arguments made in favor of the ban during the parliamentary debates. However, it was certainly considered secondary to the protection of values such as vivre ensemble, human dignity, and gender equality. Similarly, the concerns about ensuring legal unity in the kingdom, which was considered to be hampered by the latest Brussels Police Court decision, were only mentioned after "fundamental" arguments in favor of the ban were raised.

Moreover, even though the parliamentary debate focused almost exclusively on Islamic clothing, parliamentarians did not consider that the ban was specifically targeting the religious freedom of Muslims. Face veil was not perceived as a Muslim religious practice, but as a sign of withdrawal from Western society. Therefore, except for the Ecolo/Groen! Bloc, the implications of the law for religious freedom did not constitute a major worry for the deputies. However, more direct attempts such as the amendments tabled by the Flemish Liberal Party (Libertair, Direct, Democratisch) that explicitly cited Islamic clothing were also rejected. On the other hand, the Ecolo/Groen! Bloc raised concerns about the potential conflict with 
fundamental freedoms, relying on the recent reports of human rights organizations, such as Amnesty International, and Council of Europe recommendations that such general bans should not be introduced. It also warned the deputies that the ban could be perceived as indicating increasing Islamophobia. However, along with the group's request to consult the opinion of the Council of State, these recommendations were quickly dismissed, as they were deemed to be delaying the process.

\section{Changing Justificatory Repertoires Through Judicialization}

Once the law had been adopted and the conflict subsequently transposed to the judicial level, not only was the priority ranking of the different justificatory repertoires modified, but also the array of them became restricted due to judicial field effects. In its written defense submitted to the Constitutional Court, the Council of Ministers held that public security was one of the legitimate objectives of the law, along with viure ensemble. Taking off one's face veil during an identity check was not deemed sufficient, as it would prevent other forms of identification, such as witness accounts and video surveillance. Therefore, the defense of the general ban on the burqa in public was tied to the increasing presence of surveillance cameras and the notion that personal identification is less and less a matter of policing and increasingly one of permanent identifiability. Similarly, in the written defense, viure ensemble is more strongly connected to the concealing of face as a sign of unsociability and refusal to engage with the others. Therefore, judicialization of the conflict led to the standardization of the language on the part of the government, which no longer stressed other justificatory repertoires such as fighting against Islamism.

Evidently, this way of conceptualizing the ban had not appeared credible to all the actors involved in the dispute who have noted the discrepancy between the preparatory works and the language of the law. However, the head of the Muslim Executive in Belgium, as stated above, the official interlocutor between Islam and the Belgian state, told us in an interview that he believes identifiability to be "the principal motive of the law, which is sufficient to persuade everyone." His conviction should be read against the background of the disparaged status of the Muslim Executive, and therefore its noninvolvement in the court case can be seen as an attempt to protect what is left of the legitimacy of his institution. In the same vein, he also underlined that the law was not an attack on the core of Islam:

We should make the distinction between hijab and burqa. The latter is not an uncontested practice among Muslims, and it is clearly not a requisite. It is more of a regional interpretation. So, the current law does not concern us a great deal, but it should not be used as a first step to ban hijab or halal meat. (Interview, July 25, 2013)

Nevertheless, neither his nor the government's conviction to keep the burqa debate outside of the realm of religious practice was sustainable once the conflict moved to the judicial arena. Through judicialization, other actors were able to join in the debate and raise their own justificatory arguments that were closely tied to the judicial field in which 
they operate. When the law was challenged in the Belgian Constitutional Court, with a speed comparable to that of its adoption, exactly one day after its publication in the official gazette, one of the main arguments of the counter-mobilizers was the violation of religious freedom. This first application in late July 2011, which over the year was followed by three more applications, entailed pleas for both the annulment and the suspension of the law (Constitutional Court Belgium, no. 148/2011, and no. 179/2011). At this stage, there was still room for multiple justificatory repertoires to be employed by applicants who did not unanimously prioritize religious freedom as a ground on which to appeal against the ban. In fact, a variety of legal principles were cited by the applicants and the NGOs that offered third-party interventions: freedom of expression, right to a private life, freedom of circulation, right to liberty and security, right to the dignity of life, freedom of association, and the principle of nondiscrimination. Evidently, not all these pleas carried equal weight in the appeal process. However, our interview with the principal lawyer for the applicants reveals that this proliferation of principles was intentional to make the point that the law does not only target Muslims:

It was good to have applicants from different backgrounds. We had two persons who did not raise religious freedom; they were also not at all Muslims. It is not only Muslims who are affected .... All the pleas introduced were important to me. They are ultimately related to each other, but indeed freedom of religion and the right to a private life took precedence. This latter was particularly important for non-Muslims, but the Court did not follow that argument, which I find almost more important, as it applies to everyone. (Interview, September 12, 2013)

The NGO Justice and Democracy, which was cooperating closely with the principal lawyer in the case, also confirmed that its application took the form of a comprehensive strategy that sought to cover all the possible grounds by mobilizing the right people to increase its chances of success. On the other hand, Justice and Democracy itself focused more on the freedom of religion in appealing against law, which it thought was "aimed exclusively to stigmatize and attack Islam."

Public security is the only legitimate aim for this law, but other illegitimate discussions have also been held. Is this part of Islam? This is not the state's business to decide. The dignity of the person? If the person is wearing it out of her free will, it is up to her to decide the level of dignity. As for security, there is already a law regarding the police. There is no need for a new law: further clarification could be brought about with a ministerial circular, which could stipulate the unveiling of the face in course of an offense or in suspicion of an offense. We are therefore of the opinion that there is a violation of the principle of proportionality in the current law. (Interview, July 24, 2013)

Other actors involved in the case also tried to broaden the debate beyond the burqa. For instance, the francophone branch of the Human Rights League chose to introduce an appeal strictly on the principle of subsidiarity, that is, it objected to the use of the penal code as a sanctioning mechanism. However, the introduction 
of a different basis for contesting the law was not so much geared to increasing the support base for countering the ban, but instead stemmed from a cautious stance adopted to distinguish the League's position from those of the other applicants:

We did not want to take a pro position on wearing the full veil. It was not that at all, and I think for some it was pretty sensitive-they did not want the league to appear as an association that supports it. But it seemed important to us to raise this argument. We wanted to intervene only on that point. And since no other organization has raised this argument in their appeals, we suspected that the other pleas would be developed on the basis of Article 9. (Interview, September 10, 2013)

Similar concerns about appearing to support the face veil were voiced by the Flemish League of Human Rights, which also made a third-party intervention, and the Centre for Equal Opportunities and Opposition Against Racism, whose intervention in the debate remained limited to the press releases issued prior to the adoption of the ban. Even though, ultimately, the Flemish League went to the Constitutional Court to contest the law, mainly based on the disproportionality of its implications for freedom of religion and of speech, the lawyer we interviewed admitted that this was a divisive issue within the board, as some members felt uncomfortable attacking a law that "tried to protect gender equality." That is also why there was a decision to wait for initiatives from other parties first and then join in as a third party, rather than appeal against the law directly.

Yet, the decision of the court, which rejected both requests to annul or suspend the law, concentrated more on the issue of the violation of religious freedom. The court decided the ban to be constitutional, except for in places of worship, as it would be a disproportionate limitation of religious freedom to restrict "the wearing of clothing, which is an expression of a religious choice, such as the full-face veil, in such places" (Constitutional Court Belgium, no. 145/2012, p. 42, § 30). In its assessment of the legitimacy, necessity, and proportionality of the ban, the court identified three objectives on the basis of parliamentary debates, namely, public security, equality between men and women, and viure ensemble. In its own reasoning, the court connected the latter two aspects to the issue of individuality. Since the burqa allegedly takes away the capacity of being an individual, even if it is worn of one's free will, it hampers not only membership in a democratic society, which is the very core of viure ensemble, but also equality between men and women. The conceptualization of viure ensemble that builds on an understanding of social interaction that is inevitably interrupted by the concealing of the face has also gained ground in the S.A.S v. France decision of the ECtHR. Therefore, in being transposed from the political field to the judicial one, the argument of viure ensemble had to shed some of its layers and adapt to the logics of this new field. Upholding the vivre ensemble principle against individual freedoms had less to do with an Islamic fundamentalist threat to the Western and Enlightenment values than with the disruption of social living through the concealment of face. This refashioning of the argument of vivre ensemble in the course of judicialization has not only standardized justificatory repertoires for the ban, but also facilitated its spread across different settings. 
In its subsequent decisions, Dakir v. Belgium (2017) and Belcacemi and Oussar v. Belgium (2017), the ECtHR maintained its stance about viure ensemble. Systematically reiterating the S.A.S. decision, the court reaffirmed the status of vivre ensemble as a legally justifiable aim capable of limiting fundamental freedoms. The plea to take account of the specificities of the Belgian case made by the applicants in both cases and particularly by the third-party interventions in Dakir was also dismissed by the ECtHR on grounds of the principle of the margin of appreciation. On the other hand, the Belgian government already seems to have appropriated the contours of the viure ensemble in its trajectory from political to national and transnational judicial fields. The written defense of the Belgian government in both Dakir and Belcacemi and Oussar shows how it has also completely aligned its definition of viure ensemble with the judgment of the Constitutional Court and reconstructed it on the basis of prevention of social exchange. In Dakir, the government explicitly referred to the Constitutional Court arguing that the concealment of the face has the effect of depriving any possibility of individualization, which is a fundamental condition for democratic societies (Dakir v. Belgium 2017, § 32). We now turn to the Spanish case, where we discern a similar standardization of justificatory repertoires in the judicialization of the conflict-despite stark differences in the origins and judicial outcomes of controversies over full-face veils.

\section{CONTESTING THE BURQA BAN IN SPAIN}

As in Belgium, these judicial controversies are situated in broader trajectories of state policies toward religion. Spain's constitution of 1978 declares the state to be non-confessional (in Spanish original: "a-confesional") and neutral toward religion, recognizing the separation of church and state and the liberty of conscience. At the same time, the constitution stipulates that the state has established cooperative relationships with the Catholic Church and other confessions, while a separate law on religious freedom was passed in 1980. In 1989, the Spanish state officially recognized Islam as a "deeply rooted" religious tradition, and in 1992 it signed agreements with the Islamic Commission of Spain that established a series of privileges, including the right to religious accommodation in public institutions, Islamic religious education in public schools, and the right to take time off from work to celebrate Islamic holidays (Astor 2015, 252-53). To date, most high-level court cases around religion have concerned the institutional privileges of Catholicism rather than the rights of religious minorities. It is against this backdrop that judicial battles over full-face veils have emerged in two separate developments. On the one hand, there were several attempts to discuss burqa regulations in the national parliament in Madrid and the Catalan regional parliament in Barcelona. Even though they failed, we also explore these attempts to appreciate subsequent changes in political argumentation. On the other hand, there were locallevel debates in Catalan cities, which are more important as they effectively led to bans, albeit short-lived, and triggered subsequent legal counter-mobilizations.

While between 2010 and 2014, Catalonia saw a whole series of municipal regulations on face veiling, we see dynamic changes in the argumentation and legal repertoires that are mobilized in these debates and regulations resulting to an 
important degree from the parallel counter-mobilization. The political discourses in favor construed the ban (1) as an instrument in the fight against radicalism and (2) necessary for public safety and security (the ability to identify individuals), (3) as a defense of Western culture, (4) necessary for gender equality, and (5) a way of preserving people's tranquility. Arguments against the ban included the notions that (1) whether to cover one's face or not was a private matter, (2) it was prompted by populist politics and increasing Islamophobia, (3) city governments had no competence to rule on such freedoms, and (4) there was no proof that people's tranquility was being disturbed. As we shall see, in the judicial arena, the question of Muslim radicalism played only a minor role, while concerns over freedom of religion, which were peripheral to political pro-ban discourses, became central, as did concerns over gender and safety. Simultaneously, the argument regarding the defense of Western culture was linked to and reinterpreted in light of the idea of "tranquility," which ban defenders formulated in reference to the French concept of viure ensemble. Arguments against the ban remained remarkably stable across the different arenas of contestation. We now consider these changes in terms of judicial field effects step by step.

\section{A. Political Actor Constellations I: National Electoral Politics}

On June 23, 2010, Spain's second chamber, the Senate in Madrid, approved a motion presented by the main conservative party, the Partido Popular (PP, then in parliamentary opposition), to ban face veiling with the support of the Catalan center-right party Convergencia $i$ Unio (CiU). The motion suggested banning wearing the burqa in public buildings and justified it with reference to the ability to identify individuals, allow visual communication, and ensure gender equality. Most observers concluded that these parliamentary maneuvers were driven by the dynamics of Catalan regional elections. Just one month later, the national parliament rejected the motion by majority vote of the socialists.

In the Catalan parliament as well, there were three separate attempts to submit face veiling to parliamentary debate and regulation, which were put forward and rejected by different party coalitions. Thus, in 2010 the PP presented a motion in the Catalan parliament, only for the government parties (PSC/ERC/IVC) to reject it by simple majority. Three years later, on April 24, 2013, the Catalan parliament rejected another motion to debate burqa regulations, this time presented by the new center party, Ciutadans, which demanded a change in the law on religious freedom that would recognize wearing the burqa as discriminatory against women and a security threat. Parties that were pushing the issue at one point stopped it at another point, depending on whether they were in government or opposition, and accused the opposing parties of using the issue for electoral purposes. We argue that the lack of political majorities in favor of face-veiling regulations ceded these regulations as a contested terrain to local controversies. This lack is partly explained by the absence of significant right-wing populist parties ${ }^{8}$ and related tendencies to

8. For a similar impact by right-wing parties on restrictive citizenship policies, see Howard (2009). 
push parties of the center into anti-Muslim symbolic politics. Interestingly, municipal bans occurred in Catalonia as the only Spanish region with a moderately successful right-wing populist party, the Plataforma per Catalunya (Platform for Catalonia), but its electoral influence was restricted to the municipal level. As we show below, local pro-ban politicians and activists drew on local discourses to gain popular support that worked against their institutional disembedding and eventually weakened their legal value.

\section{B. Political Actor Constellations II: Contentious Urban Politics of Religious Diversity}

On October 8, 2010, the city government of Lleida in the province of Catalonia became the first municipality in Spain to pass a ban on full-face coverings in spaces belonging to the municipality (public transport, municipal archives, community halls, and social service centers) by introducing an amendment to its bylaw on public participation and coexistence (civismo y convivencia). The analysis of the origins of the conflict reveals that a variety of actors had diverse stakes in it (see Burchardt, Griera, and García-Romeral 2015). As a local policy, Lleida's burqa ban is closely tied to long-lasting conflicts between the city government and one of the two big mosque communities, one with clear Salafist tendencies. ${ }^{9}$ This conflict played itself out in disagreements over an adequate place of worship for this group and over a number of other places the community rented for different purposes. In the midst of these controversies, a small number of women wearing the full-face veil were seen in the streets of Lleida, which was interpreted as a clear sign of the increasing radicalization of local Muslims. The burqa regulation was therefore in the first place a political response to this supposed radicalization. One councilor from the PP justified the ban in the following terms: "The aim was to give a message to the people of the city and people who came from outside that immigration has to be integrated, legal, and organized. Not everything is acceptable," and added, "the burqa is the most visible and most radical sign of this Islam ... and we are not going to tolerate this, we need to put some limits" (Interview, September 12, 2013).

Significantly, there was a second mosque community, with which the city government maintained good relationships, and that was continuously hailed as well integrated and as an example of successful religious coexistence. If the city government framed the ban as a policy instrument in the fight against radicalism and a "message" to Salafists that their interpretation of religion and their vision of coexistence was undesirable, it was also meant to establish and validate criteria for legitimate religions (Griera and Burchardt 2016).

Simultaneously, in all municipalities, local burqa politics clearly followed an electoral logic, that is, they were instrumentally linked to nativist populist

9. Importantly, Salafism has become a politically charged and instrumentalized term. In the narrower scholarly understanding, the term refers to a doctrinal trend that takes its name from the first three generations of Muslims after the death of the Prophet Muhammad and concentrates on theology and purification of doctrine. 
mobilizations and prompted by potential electoral gains. Invariably, burqa debates took place in the context of municipal electoral campaigns, and several politicians from center and center-right parties conceded in interviews with us that the elections played a big role. The mayor of a medium-sized town told us: "The people were really asking for it, and I knew it would work because public support for the ban was a hundred percent" (Interview, September 15, 2013).

The larger point about burqa controversies in the political field is thus that electoral logics typically stimulate ban initiatives. However, they also force political actors aiming to create "democratic majorities" in favor of banning to foreground arguments that are politically the most expedient but might be shaky legally. One example is the reference to gender in Lleida's bylaw. A legal advisor to the city government told us in an interview that he had deleted gender equality from the draft bill as an argument in favor of the ban since, in the light of evidence produced in France on women having freely chosen to cover their faces, legal experts increasingly saw gender equality as an argument against the ban. However, as the pro-ban campaign had so deeply invested in the idea of the right to gender equality as an aspect of "our culture," the mayor insisted on this reference.

This initial constellation of actors consisting of the city government versus the Salafist mosque community quickly gave way to one that pitted the city government against sections of civil society, especially the Watani Association for Justice and Liberty, which appealed against the ban in the High Court of Justice of Catalonia (HCJC). Generally, Catalan civil society was divided over the issue. There were internal discrepancies, revealing tensions between feminist and pro-immigrant rights agendas among the political left, as well tensions within feminism, with a major Catalan grouping called the Women's Network (Dones en Xarxa) and a Lleida-based women's association with a president of Algerian origin vigorously supporting the ban. This, together with the ambivalent stances of Muslim-dominated migrant associations, made it difficult to present a unified discourse. Other Muslim-dominated migrant associations also emphasized their disagreement with the mosque leadership, oscillating in their stance between moral disapproval of burqa wearing and doubt about the legal ban as an appropriate response. Thus, the president of a migrant association remarked:

The issue of burqa wearing has to do with someone's mentality or that of the family. I think this is a personal decision or a family decision. But the burqa has nothing to do with the Muslim religion. The Quran says that women should hide their beautiful parts of their body. But this way, that you can only see the eyes and nothing else, is really a bit exaggerated. But as long as there's no trouble, let everybody wear what they want. (Interview, June 13, 2013)

\section{Changing Justificatory Repertoires}

Importantly, an initial shift in discourse related to the very definition of face covering had already occurred. Although both socialist politicians in Lleida and 
conservative politicians in Reus, who dominated their respective city councils, made no secret of the fact that the prohibition of face coverings mainly targeted Muslim women's face veils such as burqas and niqabs, eventually the municipal bylaws regulating the prohibition on face covering also included balaclavas and motorcycle helmets. This move was necessitated by the emphasis on security and identification. If full-face veiling was problematic because it hindered the security forces from identifying certain persons as potential perpetrators of crime, or even terrorist acts, this was also true for other kinds of face covering. As a result, the religious aspects of face veiling were removed from the frame and subordinated to issues of security whereby the burqa was now classified through taxonomies geared toward policing. This also prompted protest by some sectors of the left, who saw the prohibition as a new level of the surveillance of public space intent on creating transparent citizens (Burchardt and Griera 2018). Our interviews show that, while sympathetic to migrant concerns, these groups were generally hostile to religion and rejected any possible coalition building with Muslim communities. Thus, anti-ban activist politicians from the left-wing party Candidatura d'Unitat Popular (CUP) told us:

We are not collaborating with the religious groups, we are atheists, or at least secularists. We are not going to talk either with Christians, or with Jews or Muslims. We are talking with citizens .... On the contrary, in the appeal against the by-law in the High Court of Justice of Catalonia, we said to the Muslim group, you oppose the burqa issue and we do the rest. Mixing these things doesn't help anyone. (Interview, September 13, 2015)

In July 2010, the Watani Association for Justice and Liberty, led by a young Moroccan with no links to the city's Islamic communities, initiated a countermobilization by announcing that he would appeal against the ban with the help of a Barcelona-based lawyer who had accepted the case pro bono. Since neither Watani nor the lawyer had any prior contact with the field of religion or legal mobilization, they must be construed as individual entrepreneurs, disembedded from the local context. After suffering defeat in the HCJC in Barcelona, they took the case to the Spanish Supreme Court in Madrid, which eventually ruled in their favor in February 2013.

In its defense, the municipality of Lleida based itself on an article of the Law on Local Governance (Ley de Bases de Régimen Local), according to which local entities had the right to establish a regime that adequately regulated relations of community of local interest and the use of its services, facilities, infrastructure, and public spaces. The HCJC recognized that although such attempts may indeed infringe basic rights, the municipality may regulate "matters of access to basic rights, especially with regard to manifestations of community and collective life" (High Court of Justice of Catalonia 2011, 10). The disturbance of tranquility is also seen as a matter of the security of public places, and it is expressly viewed as a matter of the permanent identification of people, not occasional as required by security forces. The judges further declared that constitutionally the only limitation on 
freedom of religion is the maintenance of public order (which is different from civil security and public security), which-albeit legally underspecified-refers to externally perceivable actual conduct. In conclusion, they argued that freedom of religion never means that citizens can always behave according to their beliefs, and that the key limitation is indeed public order. The argument came full circle when the judges drew on prior judgments in which the notions of "social peace," "public peace," and "social harmony" were fashioned as semantically equivalent.

While the HCJC essentially framed the issue of face covering in terms of the "necessary" conditions of public spaces, in its judgment the Spanish Supreme Court in Madrid followed the plaintiffs in their understanding by foregrounding the right to freedom of religion. The judges stated that municipalities had no competence over regulations concerning fundamental rights and that the only constitutional tools able to do so were national laws. "A municipality cannot, of itself, establish limitations to the exercise of fundamental rights in municipal spaces" (Spanish Supreme Court 2013, 38). In addition, the court denied that this was a matter of "local interest" and stated that there were no sociological grounds justifying the ban. Simultaneously, however, the judges also declared that their verdict was not an answer to the question of whether the Spanish constitution allows a general burqa ban of the sort implemented in Belgium and France, and they left open the possibility of a state law regulating the wearing of burqas.

Significantly, while the French ban was still under consideration by the judiciaries, European human rights law had already provided the framework within which both lawyers and judges in Spain developed their justificatory repertoires, thus pointing once again toward standardization. Thus, Watani's lawyer told us:

There are no equal sentences, but there are arguments of cases related to human rights, the crucifix, the cases of Jewish discrimination etc. All this has helped me as basis to see if we had chances to reach the ECtHR, the last stage of proceedings, if the Supreme Court had said "no." ... So the last stage of the proceedings is this Court [the ECtHR], OK? So, I relied on lots of statements contained in the records and also mentioned by the Supreme Court itself in its sentence. So, I guess that the Supreme Court has interpreted international jurisprudence in this case. (Interview July 8, 2013)

Both judgments recognize that regulating full-face veiling touches on questions of fundamental rights, as they recognize that some Muslim women see wearing a burqa as a religious practice and thus as an issue of the freedom of religion. However, they are deeply divided over whether the municipality has regulatory competences based on different interpretations of the notion of "local interest" and on the existence of evidence for the disturbance of tranquility. Importantly, in the HCJC judgment, the notion of tranquility that face veiling presumably disturbs acquires the status of a property of "Western culture":

In our-Occidental_culture, hiding one's face in quotidian activities disturbs the tranquility of others because it implies the lack of visibility of 
an element that is essential in terms of identification, which is the face of the person who is hiding it. For various reasons, the same effect of disturbance is not produced in other situations, as in the exercise of certain professions, hygiene and security at the workplace, public festivities or climate-related practices. (High Court of Justice of Catalonia 2011, Art. 26.2)

While the framing of the visible face as a marker of Western culture predates the judgment, it also seems that the framing's judicial consecration imbues it with a higher status and makes it more authoritative. Thus, in an interview conducted after the HCJC decision, the mayor of Reus and pro-ban activists drew on it:

At least, in our culture the visage shows the face, and the face is the mirror of the soul. If you are happy, one can see it in your face. If you feel hate, it is reflected in the face. In conversations, through the eyes and the expressions you show what you think and whether what you say is true or whether you are lying. (Interview, January 30, 2015)

While the Spanish Supreme Court decried the lack of "sociological" evidence for the cultural argument, it was taken up prominently in S.A.S. v France (2014) and expressed through the concept of "living together" that was central to the ECtHR decision. Furthermore, the judgment ties the notion of the "tranquility of others" to ideas about the face in Western culture in legally novel ways. In the Spanish context, "tranquility of others" has hitherto been used in the context of noise disturbances caused by, for example, construction activities. Since the burqa, like any other element used for face covering, is not noisy in the same sense, a semantic shift has obviously taken place whereby "disturbance of tranquility" now seems more closely related to French or Belgian and ECtHR understandings of "living together." And while the Spanish concept of convivencia encapsulates very similar meanings of "living together," its official use is typically limited to the realm of policy. ${ }^{10}$ This raises intriguing questions of whether, and to what end, the new legal prominence of vivre ensemble may serve to transform convivencia into a legal concept in the future.

\section{CONCLUSION}

In this article, we have explored the standardization of the justificatory repertoires characteristic for the judicialization of political disputes. Combining insights from neo-institutionalism and field theory, we have argued that once claims are no

10. Referring to the experience of peaceful interreligious coexistence between Muslims, Jews, and Christians in Muslim-dominated medieval Al-Andalus, and more generally to the practice of active engagement in shared public spheres, the notion has been intellectually influential and is culturally resonant. However, it must be distinguished from the Catalan convivencia, which was coined and taken up as a general policy guideline to promote tolerance between Catalans and Spaniards after the end of the civil war (e.g., government and administrative units concerned with civil rights, integration, and social cohesion are often called "civismo y convivencia" [public spiritedness and coexistence]). 
longer made vis-à-vis imagined political constituencies but vis-à-vis judicial courts, their justification prioritizes issues of legality and constitutionality over broader arrays of political arguments-and that this standardization of justificatory repertoires, in turn, shapes subsequent public debate. The focus on burqa bans is particularly apt for analyzing these processes, since the politics of religious diversity has emerged as one of the most highly contested areas of human-rights-related jurisprudence. Adding to the existing literature on full-face veiling, we have compared two hitherto understudied cases of burqa prohibitions that give us a great opportunity to develop our argument about the standardizing effects of judicialization. Belgium and Spain differ strongly in terms of their institutional frameworks, local conflict histories, and judicial outcomes (one in which the courts upheld an existing ban, and one in which legal counter-mobilization succeeded) — and yet in both cases similar changes in justificatory repertoires can be observed over time. While the diverging judicial outcomes in both cases, at first sight, seem to contradict neo-institutionalist assumptions about convergence in transnationally structured contexts, they camouflage the standardization of justificatory repertoires occurring in the course of judicialization. More concretely, although the Spanish case diverged from Belgium in that issues over municipal competence played a major role, the actual court debates employed similar arguments (e.g., freedom of religion and "living together"). Both cases suggest that with increasing detachment from local constellations of conflict, the judicial repertoires of justification that are used by both proponents and opponents of burqa bans as well as the courts tend to become reduced to specific ways of legal reasoning, that is, to the symbolic logic of the judicial field.

Based on these empirical findings, we want to highlight four conclusions that have broader implications for the law and society literature concerned with processes of judicialization (see Roesler 2007). First, the judicialization of political disputes obviously exerts pressures on both incumbents and challengers in political fields to rearticulate their claims in legal vocabularies, thus altering their repertoires of justification upon entry into legal fields. In our two empirical cases, local mobilizations involved a variety of actors with different claims, and yet judicial battles zoomed in on the right to religious freedom and its limitations. This was so despite the fact that the laws under scrutiny actually refrained from explicitly banning Islamic clothing and could have been interpreted from other perspectives as well. What this suggests is that judicial fields have today become relatively autonomous, forcing political actors to invest in struggles over forms of symbolic capital that are specific to these fields (see Dezalay and Garth 1996).

That said, our analysis also suggests, second, that judicial fields are not fully independent from neighboring political fields. The concept of "living together" indeed pinpoints the major point of convergence between political and legal fields and illustrates what we have called practices of translation that interlock political with legal languages. In political discourses, political actors have often mobilized, inter alia, around the notion that face veiling hindered people's identifiability, which supposedly undermined social interaction and people's tranquility, as well as increased security threats. The courts took up these ideas and rearticulated them in the language of "public order" and "the rights of others." The courts' authority in defining the contours of plausible justifications thus engendered a standardization of justificatory repertoires and discursive practices across contexts. 
Third, our field-theoretical analysis adds further nuance to the study of legal transnationalism and the impact of the European human rights field. The latter turns out to be interdependent with national and local judicial fields, with influences running in both directions. French and Belgian politicians had reason to expect that the ECtHR would concede the state a wide margin of appreciation, since it had prominently emphasized this doctrine as being central to its approach to religion-state relationships in earlier decisions, most remarkably in Lautsi v. Italy (2011). Moreover, actors in Catalonia were aware of French efforts to justify the ban with reference to public order and took inspirations from them when framing their notion of disturbed tranquility. Actors situated in national and local settings strategically articulated their claims "in the shadow" of Strasbourg (see also Fokas 2015) - thereby contributing to the emergence of shared understandings that the ECtHR could later draw on when called to adjudicate on the French (and Belgian) burqa bans. The justificatory repertoire used in S.A.S. sounds strikingly familiar considering the discursive practices we encountered in the pre-S.A.S. case studies:

The Court ... can understand the view that individuals who are present in places open to all may not wish to see practices or attitudes developing there which would fundamentally call into question the possibility of open interpersonal relationships, which, by virtue of an established consensus, forms an indispensable element of community life within the society in question. The Court is therefore able to accept that the barrier raised against others by a veil concealing the face is perceived by the respondent State as breaching the right of others to live in a space of socialisation which makes living together easier." (S.A.S. v. France 2014, p. $49, \S 122$ )

The concept of "living together," having thus received judicial sanction as legitimate ground for governmental limitations of religious freedom, has now acquired even more leverage as a winning argument in political debates-unlike arguments of gender equality or humanity, which originally were also articulated in the political field. Although beyond the scope of this article, we assume that standardization of justificatory repertoires upon which our analysis has centered has contributed to the strikingly rapid spread of burqa bans throughout Europe. Spanish politicians responded to the ECtHR judgment by publicly declaring that they would now renew their efforts to regulate face veiling. The mayor of Lleida declared ${ }^{11}$ that the city government's views were fully in line with the judgment. Similarly, the mayor of Reus stated, "[t]he judgment supports our intention to prioritize security and convivencia [living together] over the freedom of religion," 12 and the city even immediately reinstated a changed version of its ban. Yet, this time around,

11. See http://ccaa.elpais.com/ccaa/2014/07/02/catalunya/1404326497_988633.html and http:// www.europapress.es/catalunya/noticia-lleida-reclama-parlament-siga-tedh-prohiba-burqa-espacios-publicos-20140702135331.html.

12. See http://www.abc.es/sociedad/20140718/abci-reus-burqa-prohibicion-201407181623.html, and http://www.lavanguardia.com/local/agencias/20140702/54411512927/reus-aplaude-la-sentencia-europeaque-avala-la-prohibicion-al-velo-integral.html. 
the Catalan Court of Justice found that the regulation violated Muslim women's right to religious freedom and annulled it, at which the municipality announced its plans for a legal appeal. Usage of this term "living together" can also be found, for instance, in the statements of the Dutch Prime Minister declaring the recent law banning the face veil in public as reflecting "a balance between people's freedom to wear the clothes they want and the importance of mutual and recognizable communication." ${ }^{\prime 13}$ It remains to be seen whether the ECtHR's S.A.S. decision will inspire and shape not only political discourses, but also further laws and policies and their specific framing of face veiling.

Fourth, our study shows that the judicialization of politics does not unambiguously advance the claims of subordinate minority groups (see also McCann 1994; Epp 1998). On the one hand, judicialization empowered human rights litigants, including cause lawyers and political activists, as well as religious, secular, and humanist organizations, and gradually increased rights consciousness in the realm of freedom of religion (Fokas 2015). Here, the Spanish story is the case in point. On the other hand, drawing on the doctrine of the margin of appreciation, the ECtHR has recognized the state-religion relationships as central to national traditions, thereby opening argumentative spaces for limiting the freedom of religion. The judicial arena has clearly proven unhelpful for face-veil wearers to advance their claims because of the spreading acceptance of the claim that the face veil undermines shared norms of sociality. If anything, the judicialization of burqa conflicts has led to the clearing of the messy terrain of diverse local regulations and bans. Yet, if one were to take a wider understanding of the effects of judicialization (McCann 2006), since the contestations around burqa wearing have built on a clear distinction between headscarf and full-face veil practices, it might be the case that this has rendered the former a more legitimate or acceptable religious practice in the public eye.

In sum, our comparative case study demonstrates not only that actors' repertoires of justification are shaped by field-specific symbolic logics, but also that their practices of translation and retranslation allow them to navigate political and judicial fields, respectively. Clearly, more research is needed to fully understand how mutual influences between the political and the legal fields shape dynamics of socio-legal mobilization and counter-mobilization and how they thus generate distinctive configurations of judicial politics.

\section{REFERENCES}

Abu-Lughod, Lila. Do Muslim Women Need Saving? Cambridge, MA: Harvard University Press, 2013.

Amiraux, Valérie. "The 'Illegal Covering' Saga: What's Next? Sociological Perspectives." Social Identities 19, no. 6 (2013): 794-806.

Astor, Avi. "Governing Religious Diversity Amid National Redefinition: Muslim Incorporation in Spain." In After Integration. Islam, Conviviality and Contentious Politics in Europe, edited by Marian Burchardt and Ines Michalowski, 247-65. Wiesbaden: Springer, 2015.

13. See http://www.independent.co.uk/news/world/europe/dutch-burqa-veil-ban-holland-votes-forpartial-restrictions-some-public-places-a7445656.html. 
Baehr, Peter, and Daniel Gordon. "From the Headscarf to the Burqa: The Role of Social Theorists in Shaping Laws Against the Veil." Economy and Society 42, no. 2 (2013): 249-80.

Beaman, Lori G. "Overdressed and Underexposed or Underdressed and Overexposed?" Social Identities 19, no. 6 (2013): 723-42.

Bourdieu, Pierre. "The Force of Law: Toward a Sociology of the Juridical Field." Hastings Law Journal 38 (1987): 805-53.

Brems, Eva (ed.). The Experiences of Face Veil Wearers in Europe and the Law. Cambridge: Cambridge University Press, 2014.

Brems, Eva, Jogchum Vrielink, and Saila Ouald Chaib. "Uncovering French and Belgian Face Covering Bans." Journal of Law, Religion and State 2, no. 1 (2013), 69-99.

Burchardt, Marian, and Mar Griera. "To See or Not to See: Explaining Intolerance Towards the 'Burqa' in European Public Space." Ethnic and Racial Studies (2018). DOI: 10.1080/ 01419870.2018.1448100.

Burchardt, Marian, Mar Griera, and Gloria García-Romeral. "Narrating Liberal Rights and Culture: Muslim Face Veiling, Urban Coexistence and Contention in Spain." Journal of Ethnic and Migration Studies 41, no. 7 (2015): 1068-87.

De Galembert, Claire. "Forcer le droit à parler contre la Burqua. Une judicial politics à la Française?" Revue française de science politique 64, no. 4 (2014): 647-68.

De Galembert, Claire, and Matthias Koenig. "Gouverner le religieux avec les juges." Revue française de science politique 64, no. 4 (2014): 631-45.

Delgrange, Xavier. "Quand la burqa passe à l'Ouest, la Belgique perd-elle le nord?" In Quand la burqa passe à l'Ouest: enjeux éthiques, politiques et juridiques, edited by David Koussens and Olivier Roy, 197-237. Rennes: Presses Universitaires de Rennes, 2014.

Dezalay, Yves, and Bryant G. Garth. Dealing in Virtue: International Commercial Arbitration and the Construction of a Transnational Legal Order. Chicago: University of Chicago Press, 1996.

DiMaggio, Paul, and Walter W. Powell. "The Iron Cage Revisited: Collective Rationality and Institutional Isomorphism in Organizational Fields." American Sociological Review 48, no. 2 (1983): 147-60.

Epp, Charles R. The Rights Revolution: Lawyers, Activists, and Supreme Courts in Comparative Perspective. Chicago: University of Chicago Press, 1998.

Fadil, Nadia. "Asserting State Sovereignty. The Face Veil Ban in Belgium." In The Experiences of Face Veil Wearers in Europe and the Law, edited by Eva Brems, 251-62. Cambridge: Cambridge University Press, 2014.

Ferejohn, John. "Judicializing Politics, Politicizing Law." Law and Contemporary Problems 65, no. 3 (2002): 41-68.

Ferrari, Alessandro, and Sabrina Pastorelli. The Burqa Affair Across Europe: Between Public and Private Space. London: Routledge, 2013.

Fligstein, Neil, and Doug McAdam. A Theory of Fields. Oxford: Oxford University Press, 2012.

Fokas, Effie. "Directions in Religious Pluralism in Europe: Mobilizations in the Shadow of European Court of Human Rights Religious Freedom Jurisprudence." Oxford Journal of Law and Religion, 4 (2015): 54-74.

Fournier, Pascale, and Erica See. "The 'Naked Face' of Secular Exclusion: Bill 94 and the Privatization of Belief." Windsor Yearbook of Access to Justice 30, no. 1 (2012): 63-77.

Fredette, Jennifer. "Becoming a Threat: The Burqa and the Contestation Over Public Morality Law in France." Law and Social Inquiry 40, no. 3 (2015): 585-610.

Ginsburg, Tom. Judicial Review in New Democracies: Constitutional Courts in Asian Cases. Cambridge: Cambridge University Press, 2003.

Griera, Mar, and Marian Burchardt. "Religión y espacio público: el conflicto en torno a la regulación del velo integral islámico." Papeles del CEIC 2 (2016): 1-28.

Grillo, Ralph, and Prakash Shah. Reasons to Ban? The Anti-Burqa Movement in Western Europe. MPI-MMG Working Paper 12-05, 2012. http://www.mmg.mpg.de/publications/working-papers/2012/wp-12-05/.

Hennette-Vauchez, Stéphanie, and Vincent Valentin. L'affaire Baby Loup ou la nouvelle laïcité. Issy-les-Moulineaux, France: Lextenso Editions, 2014. 
Hirschl, Ran. "The Judicialization of Mega-Politics and the Rise of Political Courts." Annual Review of Political Science 11 (2008): 93-118.

Howard, Marc Morjé. The Politics of Citizenship in Europe. New York: Cambridge University Press, 2009.

Hunter-Henin, Myriam. "Why the French Don't Like the Burqa: Laïcité, National Identity and Religious Freedom." International and Comparative Law Quarterly 61, no. 3 (2012): 613-39.

Joppke, Christian. "Double Standards? Veils and Crucifixes in the European Legal Order." European Journal of Sociology 54, no. 1 (2013): 97-123.

Joppke, Christian, and John Torpey. Legal Integration of Islam: A Transatlantic Comparison. Cambridge, MA: Harvard University Press, 2013.

Kanmaz, Meryem. "The Recognition and Institutionalisation of Islam in Belgium." Muslim World 92, no. 1-2 (2002): 99-113.

Kay, Tamara. "Legal Transnationalism: The Relationships Between Transnational Social Movement Building and International Law." Law and Social Inquiry 36, no. 2 (2011): 419-54.

Koenig, Matthias. "Governance of Religious Diversity at the European Court of Human Rights." In International Approaches to Governing Ethnic Diversity, edited by Jane Bolden and Will Kymlicka, 51-78. Oxford: Oxford University Press, 2015.

Kuru, Ahmet. Secularism and State Policies Toward Religion: The United States, France and Turkey. Cambridge: Cambridge University Press, 2009.

Laborde, Cécile. "State Paternalism and Religious Dress Code." ICON-International Journal of Constitutional Law 10, no. 2 (2012): 398-410.

Laurence, Jonathan. The Emancipation of Europe's Muslims. The State's Role in Minority Integration. Princeton, NJ: Princeton University Press, 2012.

Mahmood, Saba. "Secularism, Hermeneutics, and Empire: The Politics of Islamic Reformation." Public Culture 18, no. 2 (2006): 323-48.

McCann, Michael W. Rights at Work: Pay Equity Reform and the Politics of Legal Mobilization. Chicago: University of Chicago Press, 1994.

. "Law and Social Movements: Contemporary Perspectives." Annual Review of Law and Social Science 2 (2006): 17-38.

Moors, Annelies. "The Dutch and the Face-Veil: The Politics of Discomfort." Social Anthropology/ Antropologie Sociale 17, no. 4 (2009): 393-408.

Nussbaum, Martha. The New Religious Intolerance: Overcoming the Politics of Fear in an Anxious Age. Cambridge, MA: Harvard University Press, 2012.

Ouald Chaib, Saila, and Eva Brems. "Doing Minority Justice Through Procedural Fairness: Face Veil Bans in Europe." Journal of Muslims in Europe 2, no. 1 (2013): 1-26.

Parvez, Z. Fareen. "Debating the Burqa in France: The Antipolitics of Islamic Revival." Qualitative Sociology 34, no. 2 (2011): 287-312.

Pedriana, Nicholas. "From Protective to Equal Treatment: Legal Framing Processes and Transformation of the Women's Movement in the 1960s." American Journal of Sociology 111, no. 6 (2006): 1718-61.

Roesler, Shannon. "Permutations of Judicial Power: The New Constitutionalism and the Expansion of Judicial Authority." Law and Social Inquiry 32, no. 2 (2007): 545-79.

Rosenberg, Gerald. The Hollow Hope: Can Courts Bring About Social Change? Chicago: University of Chicago Press, 1991.

Selby, Jennifer. "Un/Veiling Women's Bodies: Secularism and Sexuality in Full-Face Veil Prohibitions in France and Quebec." Studies in Religion/Sciences Religieuses 43, no. 3 (2014): 439-66.

Stone Sweet, Alec. Governing with Judges: Constitutional Politics in Europe. Oxford: Oxford University Press, 2010.

Volpp, Leti. "Feminism Versus Multiculturalism." Columbia Law Review 101 (2001): 1181-1218.

Vrielink, Jogchum, Saila Ouald Chaib, and Eva Brems. "The Belgian 'Burqa Ban': Legal Aspects of Local and General Prohibitions on Covering and Concealing One's Face in Belgium." In The Burqa Affair Across Europe: Between Public and Private Space, edited by Alessandro Ferrari and Sabrina Pastorelli, 143-70. London: Routledge, 2013.

Yanasmayan, Zeynep. "Role of Turkish Islamic Organizations in Belgium: The Strategies of Diyanet and Milli Görüş." Insight Turkey 12, no. 1 (2010): 139-61. 
CASES CITED

\section{Belgium}

Constitutional Court Belgium, no. 148/2011, October 5, 2011.

_.., no. 179/2011, November 17, 2011.

_., no. 145/2012, December 6, 2012.

Police Court Brussels, no.12/2011, January 26, 2011.

Police Court Tongeren (Maaseik Department), June 12, 2006.

\section{Spain}

High Court of Justice of Catalonia, no. 489/2011, June 7, 2011.

Spanish Supreme Court, no. 4118/2011, February 6, 2013.

\section{European Court of Human Rights}

Belcacemi and Oussar v. Belgium [Chamber], no. 37798/13, July 11, 2017.

Dakir v. Belgium [Chamber], no. 4619/12, July 11, 2017.

Lautsi v. Italy [Grand Chamber], no. 30814/06, March 18, 2011.

S.A.S. v. France [Grand Chamber], no. 43835/11, July 1, 2014.

\section{STATUTES CITED}

\section{Belgium}

The Act instituting a prohibition on wearing clothing that covers the face in whole or in part, no. 2011-06-01/08, 1 June 2011.

\section{France}

The Act prohibiting concealment of the face in public space, no. 2010-1192, 11 October 2010.

\section{Spain}

Ley 7/1985, de 2 de abril, Reguladora de las Bases del Régimen Local [Law on Local Governance]. Ley Orgánica 7/1980, de 5 de julio, de Libertad Religiosa [Organic Law on Religious Freedom]. Ordenança Municipal de civisme i convivència [Municipal Bylaw on Civic Spiritedness and Living Together], changed by the Plenary of the Municipality of Lleida 8 October 2010. 